\title{
Perception of measures for dealing with Ebola disease in primary care
}

\author{
Carme Roca Saumell ${ }^{1,2}$, Anna Aguilar Margalejo ${ }^{1}$, Silvia Barro Lugo ${ }^{1}$, Dolors Sànchez Collado ${ }^{1}$ and \\ COCOOPSI Group ${ }^{\mathrm{a}}$
}

${ }^{1}$ Family Doctor, Commission for International Cooperation and Health (COCOOPSI) of the Catalan Society for Family and Community Medicine (CAMFiC), Catalonia, Spain

${ }^{2}$ Faculty of Medicine, Medicine Department, University of Barcelona, Barcelona, Catalonia, Spain

\begin{abstract}
Background: An epidemic of Ebola virus disease (EVD) occurred in West Africa in 2014. In Catalonia, primary care is the first level of healthcare so it has a key role in the detection and initial management of possible cases of EVD and in identifying contacts. Aim: This study aimed to find out how the staff of primary care centers perceived the measures for dealing with EVD. Method: An online questionnaire was distributed to all primary care workers in Catalonia during the period February-March 2015. Findings: The estimated response rate was $10.1 \%$. They reported having received training/information, that a specific circuit had been organized and that the necessary equipment was available. They considered it unlikely that a patient with suspected EVD would present at the center and were aware of the action to take but were worried about this possibility. Rigorous scientific training in international health is essential to take on new global health challenges.
\end{abstract}

Key words: Ebola virus; infectious disease; primary care

Received 16 May 2016; revised 9 November 2016; accepted 20 November 2016;

first published online 28 December 2016

\section{Introduction}

Ebola virus disease (EVD) is a viral hemorrhagic fever caused by the Ebola virus (EV) that affects humans and other primates. It is a serious illness that can reach lethality rates of $50-90 \%$. Human beings are infected by wild animals and the virus spreads by transmission from person to person, primarily by contact with blood, secretions, other body fluids, tissues or organs of persons who have developed symptoms of the disease or have died from it. The distribution area of EV coincides with the habitat of fruit bats of the family Pteropodidae, which could be the normal carrier of the virus in nature.

The incubation period is $2-21$ days. Clinically it is characterized by sudden onset of fever, intense

Correspondence to: Carme Roca Saumell, COCOOPSI CAMFiC, C/Diputació 316. 08009 Barcelona, Catalonia, Spain. Email: croca.bcn.ics@gencat.cat

${ }^{a}$ COCOOPSI Group: M. Vergara Alert, A. Tena Domingo, C. Carrasco Rauret, M. Badenes Mezquita, A. Carcasó Díaz, M.A. Gonzàlez-Martínez, B. de Gispert Uriach, L. Solsona Díaz, T. Tenas Bastida, M. Espejo Surós, E. Sequeira Aymar. weakness and muscular pain, headache and throat irritation, followed by vomiting, diarrhea, rashes, liver and kidney dysfunction, and in some cases internal and external bleeding. In the final stage patients develop multiple organ failure that can lead to death. There is currently no specific cure or preventive treatment for this disease, though much research is being done in the field. EV was first detected in 1976 in two simultaneous outbreaks in Nzara in Sudan and in Yambuku, a village in the Democratic Republic of the Congo close to the Ebola River, which gave its name to the virus [World Health Organization (WHO, 2014)].

The 2014 epidemic in West Africa probably began in Guinea Conakry in late 2013 and spread to neighboring areas of Liberia and Sierra Leone. Because there was a risk of the disease spreading to other countries because of its virulence, the pattern of transmission and the fragility of the health system in the countries concerned, on 8 August 2014 the WHO declared the outbreak a public health emergency of international concern. A coordinated international response 
was considered necessary because the magnitude and complexity of the outbreak were unprecedented (Republic of Liberia, 2007; Falleh et al., 2015; WHO, 2015). Guinea Conakry, Liberia and Sierra Leone were the epicenter of the outbreak, but patients were diagnosed with the disease in seven other countries: Mali, Nigeria, Senegal, the United States, Spain, the United Kingdom and Italy.

The first case of EVD outside the African continent was caused by secondary transmission from an imported case in Spain (Rodríguez-Caravaca et al., 2015) and gave rise to great social alarm and media coverage (Revuelta et al., 2015). The risk of importation and transmission of $\mathrm{EV}$ in the European Union is now considered minimal. The disease may be imported either by humanitarian workers or by travelers returning from affected areas. In both cases the risk is low because specific mechanisms of detection and control have been established. Protocols have also been established for reducing the risk of secondary transmission from an imported case (Ministry of Health, 2015).

Primary care (PC) is the first level of health care in Catalonia and in Spain and the ideal framework for promoting health and preventing and detecting disease. As PC is in direct contact with the community, it has a key role in detecting possible cases of EVD, initial management of the disease and identification of contacts (Arranz Izquierdo et al., 2015). To meet this challenge, PC staff urgently needed to update their knowledge of relevant aspects of EVD and receive technical training to ensure protection of themselves, their colleagues and other patients. Furthermore, health education and awareness had to be fostered among the general public (Eiros Bouza and Pérez-Rubio, 2015). To this end, the health authorities and scientific societies drew up specific guidelines and protocols for PC (Health Department, 2014; SEMFyC, 2014) and many classroom and distance learning activities were organized to improve the training of all staff (SEMERGEN, 2014; SEMG, 2014). Cascade training was used PC centers: a few professionals of each team were trained and taught to train their teammates.

In view of the urgency of the situation, the great media coverage and the alarm created by the recent outbreak of EVD, we designed a study to determine how health professionals perceived measures aimed at addressing EVD in PC.

\section{Materials and methods}

\section{Cross-sectional study}

\section{Questionnaire}

Using Google Forms we designed an online questionnaire containing 22 questions, including single and multiple-response questions. The questionnaire is shown in Table 1 . It was open from 1 February to 31 March 2015.

\section{Participants}

During the months of February and March 2015 the questionnaire entitled 'Primary Care and Ebola Disease' was distributed to all PC staff in Catalonia (Spain). It was sent by email using a 'roots' method, that is it was sent to the Catalan Society of Family and Community Medicine and the Catalan Association of Family and Community Nursing, who forwarded it to all their members. Each researcher also sent it to all their contacts and everyone was asked to collaborate by forwarding it to friends and acquaintances who met the criteria of being PC workers in Catalonia. It was also sent to the health authorities for distribution.

Whereas it could not guarantee the distribution of the questionnaire to $100 \%$ of the population who was aimed, the objective agreed was to achieve a response rate of $10 \%$.

\section{Statistical analysis}

The answers were stored directly in the Google Forms response sheet. Statistical analysis was performed using SPSS 18.0. A $\chi^{2}$ test was used for the hypothesis of independence between two categorical variables, followed by a Fisher test when the conditions were not met. A two-tailed confidence interval of $95 \%$ was used to test all the hypotheses.

\section{Results}

According to the 2013 figures (Health System Observatory of Catalonia, 2014), the 369 PC teams scattered throughout the country had a total workforce of 15408 . Of the total of 1563 respondents, $1223(78.2 \%)$ were women and $340(21.8 \%)$ were men; $68 \%$ were in the $36-55$-year age range. 
Table 1 The questionnaire primary care and ebola disease

Drawn up by the Commission for International

Cooperation and Health (COCOOPSI) of the Catalan

Society for Family and Community Medicine

(CAMFiC)

The aim is to collect information on how staff of primary care centers perceive the measures for dealing with Ebola hemorrhagic fever

We wish to reach all primary care staff in Catalonia in order to achieve a high response rate and thus obtain the most representative results possible

We hope the results will allow us to draw conclusions that will lead to improvements

It should take you about $10 \mathrm{~min}$ to respond to this questionnaire

We appreciate your participation and encourage you to pass the link on to your contacts

Thank you!

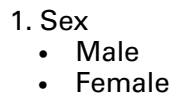

2. Age

- Under 25

- 25-35

- $36-45$

- 46-55

- 56-65

- Over 65

3. Profession

- Family doctor

- Primary care nurse

- Primary care pediatrician

- Primary care pediatric nurse

- Administrative staff

- Resident family doctor

- Resident primary care nurse

- Other

4. What health region do you work in?

- Alt Pirineu i Aran

- Lleida

- Camp de Tarragona

- Terres de l'Ebre

- Catalunya Central

- Barcelona

- Girona

5. What type of center do you work in?

- Institut Català de la Salut

- Subsidized

- Entitat de Base Associativa (cooperative health center)

- Other

6. At the center where you work, have you received any of the following types of training on Ebola disease (you can check more than one option)?

- Classroom training at the center

- Classroom training outside the center

- Distance training (PowerPoint, videos, etc.)
Table 1 (Continued)

- Trainer training

- Training emails with protocols, circuits, etc.

- Training has been scheduled but not given yet

- Other

- I have received no training

7. At the center where you work, have you received any of the following types of information on Ebola disease (you can check more than one option)?

- Emails with information on the state of the disease

- Posters on the disease

- Information on the disease through other information systems such as SMS, WhatsApp, written information, notes in the health IT system, etc.

- I have received no information on the disease

- Other

8. What other sources of information/training have you consulted on your own initiative (you can check more than one option)?

- Accredited international websites (CDC, WHO, etc.)

- Accredited national websites (CAMFiC, Barcelona Medical Association, Catalan Ministry of Health, AIFiC, SEMFyC, Spanish Ministry of Health, etc.)

- Social networks (Twitter, Facebook, YouTube, etc.)

- Other websites

- Exhibitions, talks and radio or television debates

- I have not consulted any other sources

- Other

9. In general, how much information/training on Ebola disease have you have received?

- A lot

- Quite a lot

- Enough

- Not enough

- None

10. In general, how would you rate the quality of information/training on Ebola disease that you have received?

- Excellent (broad, clear and useful)

- Good (sufficient, clear and useful)

- Poor (confusing, contradictory or unhelpful)

- Very poor (very confusing or very contradictory or not suited to the center)

- I have not received any

11. Has a specific circuit been organized and have the room and the material to be used in a suspected case of Ebola disease been clearly identified at the center where you work?

- Yes

- No

- Don't know

12. Have information posters about Ebola disease been put up in the center where you work?

- Yes

- No

- Don't know

Primary Health Care Research \& Development 2017; 18: 282-290 
Table 1 (Continued)

13. Do you have basic protective equipment (surgical cap, surgical mask, short nitrile gloves and waterproof gown) at the center where you work?

- Yes

- No

- Don't know

14. Do you have personal protective equipment (surgical caps, goggles, FFP2 grade mask, short nitrile gloves, long latex gloves, coveralls and overboots) at the center where you work?

- Yes

- No

- Don't know

15. Has specific training on putting on and removing individual protective equipment been given at the center where you work? Did you attend?

- Yes and I attended

- Yes but I did not attend

- No training has been given

- Don't know

16. In your opinion, how likely is it that a patient suspected of Ebola disease will present at your center?

- Very likely

- Fairly likely

- Fairly unlikely

- Unlikely

- Highly unlikely

17. How confident are you about the action you must take if a patient suspected of Ebola disease presents at your center?

- Very confident

- Confident

- Not very confident

- Not at all confident

18. How worried are you about the possibility of dealing with a suspected case of Ebola disease?

- Extremely worried

- Very worried

- Fairly worried

- A little worried

- Not worried

19. What is the incubation period of Ebola disease?

- 7-21 days with an average of 12 days

- 1-21 days with an average of 18 days

- 2-21 days with an average of 8 days

- 10-21 days with an average of 14 days

- Don't know

20. Which of these statements about the mechanisms of transmission of the disease is true?

- It is transmitted by direct contact with fluids and/or secretions or indirect contact with objects contaminated with body fluids of asymptomatic patients and by sexual transmission

- It is transmitted by direct contact with fluids and/or secretions or indirect contact with objects
Table 1 (Continued)

contaminated with body fluids of symptomatic patients and by sexual transmission

- Transmission from an asymptomatic person to a healthy person is considered the main mechanism of transmission

- Transmissibility decreases as the disease evolves

- Don't know

21. What are the clinical manifestations of Ebola disease?

- It begins abruptly with fever, muscular pain, weakness, headache and throat irritation

- It evolves with vomiting, diarrhea, skin rash, kidney and liver failure, and possible massive internal and external bleeding

- In the final stage, patients develop multiple organ failure

- All of the above

- Don't know

22. Mark the answer you think is correct

- Ebola disease is highly contagious

- The risk of infection by Ebola virus in Catalonia is considered very high

- The fatality rate in Africa is $50-90 \%$

- There is a specific treatment

Observations: If you wish, here you can write anything not dealt with in the above questions that you think might be interesting for the study

Thank you!

Your response has been processed correctly

We appreciate the time you have spent

We are committed to publishing the general results

Assuming an ideal setting in which the survey reached $100 \%$ of PC staff in Catalonia, which cannot be guaranteed, the response rate was $10.1 \%$. Table 2 shows the distribution of responses according to profession. Table 3 shows the distribution of the respondents according to health region and type of center. Table 4 shows the training and information on EVD provided by the centers and the training and information obtained by the respondents on their own initiative. Physicians responded that they had received less information $(P=0.008)$ and had obtained more training and information on their own initiative $(P=0.007)$ than the other professionals. Administrative staff had obtained less training information on their own initiative $(P<0.0001)$ than the other.

Regarding the information and training received, $80.1 \%$ of respondents considered that they had received enough, quite a lot or a lot 
Table 2 Response rate according to profession

\begin{tabular}{lccc}
\hline & $\begin{array}{l}\text { No. of primary care workers } \\
\text { to whom the survey was addressed }\end{array}$ & $\begin{array}{l}\text { Workers who responded } \\
\text { to the survey }\end{array}$ & \% response \\
\hline Total & 15408 & 1563 & 10.1 \\
Family doctors & $4391(28.5 \%)$ & $775(49.6 \%)$ & 17.6 \\
Nurses & $5100(33.1 \%)$ & $433(27.7 \%)$ & 8.5 \\
Administrative staff & $3190(20.7 \%)$ & $203(13 \%)$ & 6.4 \\
Pediatricians & $1032(6.7 \%)$ & $39(2.5 \%)$ & 3.8 \\
Social workers & $247(1.6 \%)$ & $6(0.4 \%)$ & 2.4 \\
Others & $1448(9.4 \%)$ & $53(3.4 \%)$ & 3.7 \\
\hline
\end{tabular}

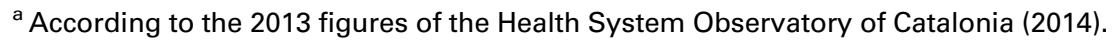

Table 3 Distribution of respondents by health region and type of center

\begin{tabular}{lc}
\hline & $n(\%)$ \\
\hline Health region & \\
Barcelona & $868(55.5)$ \\
Girona & $231(14.8)$ \\
Central Catalonia & $182(11.6)$ \\
Tarragona & $127(8.1)$ \\
Lleida & $112(7.2)$ \\
Alt Pirineu and Aran & $23(1.5)$ \\
Terres de I'Ebre & $20(1.3)$ \\
Type of center & \\
Institut Català de la Salut & $1122(71.8)$ \\
Subsidized & $298(19.1)$ \\
EBA & $78(5)$ \\
Others & $65(4.2)$ \\
\hline
\end{tabular}

$\mathrm{EBA}=$ Entitats de Base Associativa (cooperative health centers)

and $75.6 \%$ considered that its quality was good or excellent.

Organization of the PC center: Of the respondents, $91.6 \%$ stated that a specific circuit had been organized at the center and that the room and the material to be used for a suspected case of EVD had been clearly identified; $46.2 \%$ that posters on the disease had been hung up in the center; $91.2 \%$ that basic protection kits (surgical caps, surgical masks, short nitrile gloves and waterproof gowns) had been prepared ( $5 \%$ did not know); $79.8 \%$ that individual protective equipment (surgical caps, goggles, FFP2 grade mask, short nitrile gloves, long latex gloves, coveralls and overboots) had been prepared $(10.5 \%$ did not know); $77.4 \%$ that specific training in putting on and removing personal protective equipment had been carried

Primary Health Care Research \& Development 2017; 18: 282-290
Table 4 Training and information provided by the center

\begin{tabular}{|c|c|}
\hline & $n(\%)^{a}$ \\
\hline \multicolumn{2}{|l|}{ Training given by the center } \\
\hline Classroom training at the center & $1286(83)$ \\
\hline Classroom training outside the center & $298(19.2)$ \\
\hline Distance training (PowerPoint, videos, etc.) & $420(27.1)$ \\
\hline Trainer training & $206(13.3)$ \\
\hline Training emails with protocols, circuits, etc. & $877(56.6)$ \\
\hline Training has been scheduled but not given yet & $29(1.9)$ \\
\hline I have received no training & $36(2.3)$ \\
\hline \multicolumn{2}{|l|}{ Information given by the center } \\
\hline $\begin{array}{l}\text { Emails with information on the state of } \\
\text { Ebola disease }\end{array}$ & $1340(87)$ \\
\hline Posters on Ebola disease & $331(21.5)$ \\
\hline $\begin{array}{l}\text { Other information systems such as SMS, } \\
\text { WhatsApp, written information, notes in } \\
\text { the health IT system, etc. }\end{array}$ & $644(41)$ \\
\hline I have received no information & $43(3)$ \\
\hline \multicolumn{2}{|c|}{ Sources of information/training consulted on own initiative } \\
\hline $\begin{array}{l}\text { Accredited international websites (CDC, } \\
\text { WHO, etc.) }\end{array}$ & $624(40.4)$ \\
\hline $\begin{array}{l}\text { Accredited national websites (CAMFiC, } \\
\text { Barcelona Medical Association, Catalan } \\
\text { Ministry of Health, AIFiC, SEMFyC, } \\
\text { Spanish Ministry of Health, etc.) }\end{array}$ & $974(63.1)$ \\
\hline $\begin{array}{l}\text { Social networks (Twitter, Facebook, } \\
\text { YouTube, etc.) }\end{array}$ & $197(12.8)$ \\
\hline Other websites & $190(12.3)$ \\
\hline $\begin{array}{l}\text { Exhibitions, talks and radio or television } \\
\text { debates }\end{array}$ & $188(12.2)$ \\
\hline I have not consulted any other sources & $236(15.3)$ \\
\hline Others & $62(4)$ \\
\hline
\end{tabular}

a The respondents were able to choose multiple responses.

out; and $63 \%$ that they had attended such training (3.9\% did not know).

Table 5 shows the respondents' subjective perception of the likelihood of a patient suspected of 
Table 5 Subjective perception

\begin{tabular}{|c|c|}
\hline $\begin{array}{l}\text { In your opinion, how likely is } \\
\text { it that a patient suspected of } \\
\text { Ebola disease will present } \\
\text { at your center? }\end{array}$ & $\begin{array}{l}\text { - Very likely } 7(0.5 \%) \\
\text { - Fairly likely } 76(4.9 \%) \\
\text { - Fairly unlikely } 793(51 \%) \\
\text { - Unlikely } 327(21 \%) \\
\text { - Highly unlikely } 351 \\
\text { (22.6\%) }\end{array}$ \\
\hline $\begin{array}{l}\text { How confident are you of the } \\
\text { action you must take if a } \\
\text { patient suspected of Ebola } \\
\text { disease presents at your } \\
\text { center? }\end{array}$ & $\begin{array}{l}\text { - Very confident } 343(22.1 \%) \\
\text { - Confident } 947(61.1 \%) \\
\text { - Not very confident } 226 \\
\text { ( } 14.6 \%) \\
\text { - Not at all confident } 33 \\
(2.1 \%)\end{array}$ \\
\hline $\begin{array}{l}\text { How worried are you about } \\
\text { the possibility of dealing } \\
\text { with a suspected case of } \\
\text { Ebola disease? }\end{array}$ & $\begin{array}{l}\text { - Extremely worried } 97 \\
\text { (6.2\%) } \\
\text { - Very worried } 160(10.3 \%) \\
\text { - Fairly worried } 339(21.8 \%) \\
\text { - A little worried } 605(38.9 \%) \\
\text { - Not worried } 356(22.9 \%)\end{array}$ \\
\hline
\end{tabular}

EVD presenting at the PC center, their confidence about dealing with it and the extent to which they were worried about it. Women worried more about the possibility of having to deal with a suspected case of EVD than men $(P=0.0001)$.

Clinical knowledge: Of the respondents, 442 $(28.6 \%)$ responded correctly on the incubation period, $1287(82.9 \%)$ on the mechanisms of transmission of the disease and $1400(89.9 \%)$ on the clinical manifestations. In response to Question 22, a total of $772(49.7 \%)$ chose the wrong answer that EVD is highly contagious and 761 (49\%) chose the right answer that the fatality rate in Africa is $50-90 \%$.

Table 6 shows the the distribution of the frequencies according to sex, age and type of staff and the Qui square analysis results ( $P$-values).

\section{Discussion}

The EVD epidemic has raised awareness of the globalization of infectious diseases among the general public and health professionals (Trilla, 2014). This globalization is a challenge for health systems, which must improve and provide a coordinated response to possible future threats to public health (Dzau and Rodin, 2015), such as the current Zika virus epidemic (WHO, 2016).
PC teams have responsibilities in international health alerts: early detection, early management of possible cases and monitoring and management of potential infection. As in many other infectious diseases, good coordination between health authorities, specialized hospital units, family doctors and other health professions is a key factor.

A literature search found no similar studies to compare the results. In our study, half the respondents were physicians: the fact that the study was conceived by physicians may have increased the dissemination and interest among this group. Half the respondents worked in urban areas. They had received training (mainly in the classroom) and information (mainly by email) and had sought training and information on their own initiative (especially on accredited national websites) and their evaluation of both the quantity and quality of the training and information received was good. Technology now plays an important role in the transmission of information (Gidado et al., 2015). However, the training was mostly in classrooms. Research is needed to compare the level of knowledge obtained through online training versus classroom training, taking into account the current trend of promoting selfdirected learning skills (Monroe, 2016).

A study conducted in the North Metropolitan Area of Barcelona (Valerio et al., 2015) assessed knowledge of viral hemorrhagic fever among PC doctors and nurses before a trainer training workshop on EVD. The results (117 responses from 138 participants) indicated a low knowledge (78.6\%), and having attended specific training was significantly and independently associated with having suitable knowledge $(P<0.001)$; OR $=8.6$ (CI 95\%: 3.199-23.623).

In most centers a specific circuit had been organized and the room and the material to be used for patients with suspected EVD had been identified. Basic protective equipment and personal protective equipment had been prepared, and specific training in their use had been given to the staff.

In analyzing the responses on subjective perception, $77 \%$ were worried about the possibility of having to deal with a patient with suspected EVD at the center, although they considered it not very likely, unlikely or highly unlikely and were confident of the action to be taken. As stated by Blaya-Novakova V (Blaya-Nováková et al., 2015) 'we have to keep in mind that physicians are not 


\begin{tabular}{|c|c|c|c|c|c|c|c|c|c|}
\hline & Training & Information & Training and & Clinical knov & wledge & & Subjective per & rception about & \\
\hline & & & $\begin{array}{l}\text { consulted } \\
\text { on own } \\
\text { inititatived }\end{array}$ & $\begin{array}{l}\text { Incubation } \\
\text { period }\end{array}$ & $\begin{array}{l}\text { Mechanisms of } \\
\text { transmission }\end{array}$ & $\begin{array}{l}\text { Clinical } \\
\text { manifestations }\end{array}$ & $\begin{array}{l}\text { Likelihood of } \\
\text { a patient } \\
\text { suspected of } \\
\text { EVD } \\
\text { presenting at } \\
\text { the PC center }\end{array}$ & $\begin{array}{l}\text { Their } \\
\text { confidence } \\
\text { about } \\
\text { dealing } \\
\text { with it }\end{array}$ & $\begin{array}{l}\text { The extent } \\
\text { to which } \\
\text { they were } \\
\text { worried } \\
\text { about it }\end{array}$ \\
\hline \multicolumn{10}{|l|}{ Sex } \\
\hline Female & $1178(97.1 \%)$ & $1166(97 \%)$ & $1018(84.3 \%)$ & $338(27.6 \%)$ & $1002(81.9 \%)$ & 1094 (89.4\%) & $1157(94.6 \%)$ & $1004(82 \%)$ & $968(79.1 \%)$ \\
\hline Male & $329(97.9 \%)$ & $328(97 . \%)$ & 291 (86.3\%) & $104(30.5 \%)$ & $285(83.8 \%)$ & $306(90 \%)$ & $322(94.7 \%)$ & $296(87 \%)$ & 233 (68.5\%) \\
\hline$p$ & $\mathrm{~ns}^{*}$ & ns & ns & ns & $\mathrm{ns}$ & ns & ns & 0.03 & $<0.001$ \\
\hline$<35$ and $>55$ & 497 (97\%) & $480(97.6 \%)$ & 438 (87.6\%) & $137(27.4 \%)$ & $414(82.8 \%)$ & 447 (89.4\%) & $451(89.3 \%)$ & 412 (81.6\%) & 391 (77.4\%) \\
\hline $35-55$ & 1024 (97.4\%) & $1014(96.7 \%)$ & $890(83.7 \%)$ & $305(28.7 \%)$ & $873(82.1 \%)$ & $953(89.6 \%)$ & $1009(95.3 \%)$ & $892(84.3 \%)$ & $814(76.9 \%)$ \\
\hline$p$ & ns & ns & 0.048 & ns & ns & ns & $<0.0001$ & ns & ns \\
\hline Physicians & $855(96.6 \%)$ & $845(96 \%)$ & $767(87.3 \%)$ & $254(28.7 \%)$ & $780(88 \%)$ & $844(95.2 \%$ & 846 (95.5\%) & $728(82.8 \%)$ & $675(76.2 \%)$ \\
\hline Not physicians & 652 (97.4\%). & $649(98.3 \%)$ & $542(81,3 \%)$ & $178(26.7 \%)$ & $507(74.8 \%)$ & $556(82.1 \%)$ & $634(93.6 \%)$ & $572(83.6 \%)$ & $530(78.2 \%)$ \\
\hline$p$ & ns & 0.008 & 0.007 & ns & $<0.0001$ & 0.007 & ns & & \\
\hline Nurse & $438(98 \%)$ & $441(98,8 \%)$ & $380(85 \%)$ & $134(29.7 \%)$ & $362(80.2 \%)$ & $399(88.4 \%)$ & $401(92.6 \%)$ & 370 (82\%) & $359(79.6 \%)$ \\
\hline Not nurse & $1069(97 \%)$ & $1053(96.2 \%)$ & $929(84.7 \%)$ & $308(27.7 \%)$ & $925(83.1 \%)$ & $1001(90 \%)$ & $1077(95 \%)$ & $930(83.6 \%)$ & $846(76 \%)$ \\
\hline $\begin{array}{l}p \\
\text { Administrative staff }\end{array}$ & $\begin{array}{l}\text { ns } \\
209 \text { (96.7\%) }\end{array}$ & $\begin{array}{l}\text { ns } \\
207(97.6 \%)\end{array}$ & $\begin{array}{l}\text { ns } \\
159(74.6 \%)\end{array}$ & $\begin{array}{l}\text { ns } \\
54(24.5 \%)\end{array}$ & $\begin{array}{l}\text { ns } \\
145(66 \%)\end{array}$ & $\begin{array}{l}\text { ns } \\
154(70 \%)\end{array}$ & $\begin{array}{l}\text { ns } \\
210(95.4 \%)\end{array}$ & $\begin{array}{l}\text { ns } \\
192(87.2 \%)\end{array}$ & $\begin{array}{l}\text { ns } \\
168(76.3 \%)\end{array}$ \\
\hline Not administrative & $1298(97.3 \%)$ & $1287(96.9 \%)$ & $1150(86.4 \%)$ & $388(28.9 \%)$ & $1142(85 \%)$ & 1246 (92.7\%) & $1270(94.5 \%)$ & $1108(82.5 \%)$ & $1037(77.2 \%)$ \\
\hline$p$ & ns & ns & $<0.0001$ & ns & $<0.0001$ & 0.0002 & ns & ns & ns \\
\hline
\end{tabular}

$\mathrm{ns}^{*}$, no statistically significant differences. 
immune to experiencing fear in the face of EVD, that they may worry about the legal consequences of not detecting EVD in a patient or feel responsible for possibly exposing the rest of the healthcare team, other patients and ultimately even their own family to a severe disease.' The mechanisms of infection and clinical manifestations were well known.

The main limitation was that we did not know the denominator for calculating the response rate. To minimize this limitation, we decided to work with the most optimistic hypothesis possible (the questionnaire reached $100 \%$ of the people to whom it was addressed). We also tried to minimize the non-response bias by mass emailing with the link to the questionnaire and a reminder half-way through the study period. A study of the perception of risk of EVD in the general German population (Rübsamen et al., 2015) through online questionnaires obtained a response rate of $9 \%$.

In conclusion, the perception of PC staff in Catalonia who responded to the survey on EVD was that they had received training and information and that the centers had organized the specific circuit and the necessary equipment. The respondents considered it unlikely that a patient with suspected EVD would present at the PC and were aware of the action to be taken in such cases but they were worried about this possibility.

Careful, rigorous scientific training in international health issues at both undergraduate and graduate level is now essential to take on the new challenges of global health.

\section{References}

Arranz Izquierdo, J., Gutiérrez Pérez, M.I. and Molero García, J.M. 2015: La infección por el virus Ébola. Podemos hacerlo mejor. Atención Primaria 47, 71-72.

Blaya-Nováková, V., Lópaz-Pérez, M.Á., Méndez-Navas, I., Domínguez-Berjón, M.F. and Astray-Mochales, J. 2015: Dealing with Ebola virus disease in Spain: epidemiological inquiries received by the Department of Public Health Alerts, April to December 2014. EuroSurveillance 20, 1-8, pii=30058. Retrieved 6 December 2016 from https:// doi.org/10.2807/1560-7917.ES.2015.20.44.30058.

Dzau, V.J. and Rodin, J. 2015: Creating a Global Health Risk Framework. New England of Journal Medicine 373, 991-93.

Eiros Bouza, J.M. and Pérez-Rubio, A. 2015: Ébola y virus emergentes. Atención Primaria 47, 131-33.
Falleh, M., Skrip, L.A., D'Harcourt, E. and Gavani, A.P. 2015: Strategies to prevent future Ebola epidemics. Lancet $386,131$.

Gidado, S., Oladimeji, A.M., Roberts, A.A., Nguku, P., Nwangwu, I.G., Waziri, N.E., Shuaib, F., Oguntimehin, O., Musa, E., Nzuki, C., Nasidi, A., Adewuyi, P., Daniel, T., Olayinka, A., Odubanjo, O. and Poggensee, G. 2015: Public knowledge, perception and source of information on Ebola virus disease - Lagos, Nigeria; September, 2014. PLoS Currents 7. Retrieved from https://doi.org/10.1371/currents. outbreaks.0b805cac244d700a47d6a3713ef2d6db.

Health Department 2014: Departament de Salut. Generalitat de Catalunya. Procediment d'actuació davant d'un cas de sospita de febre hemorràgica pel virus de l'Ebola. Retrieved 14 September 2015 from https://www.youtube.com/watch? $\mathrm{v}=$ Fy0OArICNPI.

Health System Observatory of Catalonia 2014: Observatori del Sistema de Salut de Catalunya. Results Center. Primary Care Area. 2013 figures. Barcelona: Agència de Qualitat i Avaluació Sanitàries de Catalunya. Departament de Salut. Generalitat de Catalunya. Retrieved 9 November 2016 from http://observatorisalut.gencat.cat/web/.content/ minisite/observatorisalut/ossc_central_resultats/informes/ documents/Central_Resultats_atencio_primaria_dades_2013. pdf.

Ministery of Health 2015: Ministerio de Sanidad Servicios Sociales e Igualdad. Evaluación del riesgo para España de la epidèmia de fiebre hemorràgica por el virus de Ébola en África Occidental. 31 July, pp. 1-7. Retrieved 9 November 2016 from http://www.msssi.gob.es/profesionales/saludPublica/ ccayes/alertasActual/ebola/documentos/Ebola_final_2015.pdf.

Monroe, K.S. 2016: The relationship between assessment methods and self-directed learning readiness in medical education. International Journal of Medical Education 7, 75-80.

Republic of Liberia 2007: Ministry of Health and Social Welfare. National Health Policy: National Health Plan 2007-2011, Monrovia.

Revuelta, G., De Semir, V., Armengou, C., Cots, E., Gonzalo, C., Saladié, N. and Sarukhan, A. 2015: Informe Quiral 2014: La comunicación pública sobre la enfermedad del Ébola. Fundación Vila Casas and Centro de Estudios de Ciencia, Comunicación y Sociedad (Universidad Pompeu Fabra), Barcelona. Retrieved 9 November 2016 from http://ccs.upf. edu/wp-content/uploads/InformeQuiral2014.

Rodríguez-Caravaca, G., Timermans, R., Parra-Ramírez, J.M., Domínguez-Hernández, F.J., Algora-Weber, A., DeladoIribarren, A. and Hermida-Gutiérrez, G., Ebola virus Management Committee 2015: Health-care management of an unexpected case of Ebola virus disease at the Alcorcón Foundation University Teaching Hospital. Enfermedades Infecciosas y Microbiología Clínica 33, 228-32.

Rübsamen, N., Castell, S., Horn, J., Karch, A., Ott, J.J., Raupach-Rosin, H., Zoch, B., Krause, G. and Mikolajezyk, R.T. 2015: Ebola risk perception in Germany, 2014. Emerging Infectious Diseases 21, 1012-18. 
SEMERGEN 2014: Sociedad Española de Medicina de Atención Primaria. Los médicos de Atención Primaria se forman para atender una presumible 'avalancha' de demanda de información sobre el virus Ébola. Retrieved 9 November 2016 from http://www.semergen.es/semergen/sites/default/ files/noticias/np_ebola_en_atencion_primaria_ok.pdf.

SEMFyC 2014: Sociedad Española de Medicina Familiar y Comunitaria. Enfermedad por virus Ébola. Recomendaciones para la Atención Primaria. Retrieved 9 November 2016 from http://www.semfyc.es/es/biblioteca/ virtual/detalle/Recomendaciones_Ebola_AP/.

SEMG 2014: Sociedad Española de Médicos Generales y de Familia (SEMG). Infección por virus Ebola. Aspectos básicos de actuación en atención primaria, 2014. Retrieved 1 October 2015 from http://www.semg.es/agencia-deprensa/notas-de-prensa/1051-ebola-2014-1.html.
Trilla, A. 2014: Ébola ad portas. Medicina Clínica (Barcelona) 143, 492-94.

Valerio, Ll, Pérez-Quílez, O., Roure, S., Fructuoso, E., Amilibia, I., Moreno, N., Sañudo, L., Bocanegra, C. and Martínez-Cuevas, O. 2015: When information does not translate into knowledge. Ebola and hemorrhagic fevers knowledge among primary care physicians and nurses. Open Journal of Preventive Medicine 5, 122-27.

World Health Organization (WHO) 2014: Fact sheet no. 103, April 2014. Retrieved 9 November 2016 from http://www. who.int/mediacentre/factsheets/fs103/es/.

World Health Organization (WHO) 2015. Ebola situation report-20 May 2015. Geneva: World Health Organization.

World Health Organization (WHO) 2016: Zika virus and potential complications. Retrieved 9 November 2016 from http://www.who.int/emergencies/zika-virus/en/. 